\title{
Revolutionizing Towards Sustainable Agricultural Systems: The Role of Energy
}

\author{
Ilaria Zambon ${ }^{1, *(\mathbb{D}}$, Massimo Cecchini ${ }^{1}(0)$, Enrico Maria Mosconi ${ }^{2}\left(\mathbb{D}\right.$ and Andrea Colantoni ${ }^{1}(\mathbb{D}$ \\ 1 Department of Agricultural and Forestry Sciences (DAFNE), Tuscia University, \\ Via San Camillo de Lellis, I-01100 Viterbo, Italy; cecchini@unitus.it (M.C.); colantoni@unitus.it (A.C.) \\ 2 Department of Economics Engineering, Society and Business Organization, Tuscia University, \\ Via del Paradiso 47, I-01100 Viterbo, Italy; enrico.mosconi@unitus.it \\ * Correspondence: ilaria.zambon@unitus.it
}

Received: 29 July 2019; Accepted: 23 September 2019; Published: 25 September 2019

\begin{abstract}
Innovations play a significant role in the primary sector (i.e., agriculture, fisheries and forestry), ensuring a greater performance towards bioeconomy and sustainability. Innovation is being progressively applied to examining the organization of joint technological, social, and institutional modernizations in the primary sector. Exploring the governance of actor relations, potential policies, and support structures is crucial in the phase of innovation, e.g., during research activities, often applied at the national or sectorial scale. However, when opposing normative guidelines for alternative systems of agriculture arise (e.g., the industrial agriculture paradigm), modernizations in agricultural and forestry may contribute to outlining more sustainable systems. To date, innovations in the primary sector do not seem as advanced as in other sectors, apart from industrial agriculture, which sometimes appears to be the most encouraged. The present review aims to shed light on innovations that have been identified and promoted in recent years in the primary sector, including agriculture and forestry. The need to pursue sustainable development in this sector requires the inclusion of a fourth dimension, namely energy. In fact, energy sustainability is an issue that has been much discussed in recent years. However, the need for progressive technological progress is indispensable to ensure long-lasting energy efficiency. The aim is to understand what innovations have been implemented recently, highlighting opportunities and limitations for the primary sector.
\end{abstract}

Keywords: innovation; agriculture; forestry; energy; sustainability

\section{Introduction}

Innovations play a significant role in the primary sector (i.e., agriculture, fisheries and forestry), ensuring a greater performance towards bioeconomy and sustainability [1-3]. Innovation has been progressively applied to examine the organization of joint technological, social and institutional modernizations in the primary sector [4-6]. Exploring the governance of actor relations, potential policies, and support structures is crucial in the phase of innovation, e.g., during research activities [7], often applied at the national or sectorial scale [5,7]. However, when opposing normative guidelines for alternative systems of agriculture arise (e.g., the industrial agriculture paradigm), modernizations in agriculture and forestry may contribute to outlining more sustainable systems [5,8-12]. To date, innovations in the primary sector do not seem as advanced as in other sectors, apart from industrial agriculture, which sometimes appears to be the most encouraged nowadays [10]. This leads to the need (i) to adopt a multifunctional approach to agriculture, (ii) to focus explicitly on ecological aspects, and (iii) to take on technological advances that involve different disciplines $[5,13,14]$.

Innovations in the primary sector can enable a cooperative achievement emerging from different actors (frequently in new mixtures), providing innovative modes of production and new organizational 
structures and activities to better support widespread learning, adapting, and adjusting [5,15]. By permitting relations across different stakeholders (e.g., professional, sectoral, organizational, or cultural), the involved actors can (i) experiment together, (ii) propose new technologies, practices, and institutions, and (iii) support evolution towards a more sustainable agriculture [5,15]. Thanks to the interactions among different actors, changes to more sustainable agriculture comprise the development of modernization $[15,16]$.

Complex challenges facing an evolution towards more sustainable agricultural and forestry systems are often connected to resource competition (e.g., energy, water, land, biodiversity), socio-economic apprehensions (e.g., community development, rural livelihoods, emerging markets), and environmental integrity (e.g., climate change) [17-20]. Such challenges characteristically span numerous natural resource management systems (e.g., agriculture and forestry, but also water, conservation and energy) and related ecosystem services (including the provision, regulatory, cultural and support services) $[5,21,22]$. Agriculture-related fields identify the requirement for better adoptive relationships across scales and sectors to report multifaceted sustainability trials [13,23]. Consequently, more networked methods are required to move toward innovation and sustainable agriculture, with the aim to simplify the boundary crossing and to coordinate actors across different spatial scales [5]. With reference to crossing scales, changes toward sustainability require the skill to move innovation processes ahead by working across scales [14,24]. Correspondingly, landscape approaches have the latent character to mature more combined approaches for sustainable agriculture and to enable the compulsory connections among the systems, services and, sectors interested in agricultural and forestry areas $[16,25,26]$. For instance, multifunctionality and circular economies are some of the main ideas in sustainable agricultural and forestry systems [5]. Multifunctionality includes production, environmental, and human features of agriculture, which are crucial to sustainability $[19,27,28]$. Sectoral divisions (e.g., agriculture versus energy) or sub-sectoral divides within agriculture owing to specialization (e.g., separation of crop and livestock sectors) have long delayed endorsing multifunctional methods in agriculture and practical crossovers with non-agricultural sectors [5,27,29-31].

The present review aims to shed light on innovations that have been identified and promoted in recent years in the primary sector, including agriculture and forestry. The need to pursue sustainable development in this sector perceives the requirement to include a fourth dimension, namely energy [32]. Examining one of the recent notions of 'sustainability', energy can be assumed as the fourth dimension of sustainability. With the four sustainable dimensions (energy, economy, society and environment), rural districts can provide greater maintainable growth, also focusing on a sustainable (energy) future, which in literature is perceived by the "agro-energy districts" [32-36]. However, very often such innovative realities present their intrinsic limits. For this reason, today, the need for progressive technological progress is indispensable to ensure long-lasting energy efficiency. The general aim of the present review is to understand what innovations have been carried out recently, highlighting opportunities and limitations for the primary sector.

\section{Energy for a Sustainable Development in the Primary Sector}

Agriculture is one of the most significant sectors, which is characterized by the greatest potential for sustainable economic development $[5,7,9,16,28-39]$. Specifically, renewable sources represent good alternatives to fossil resources in the primary sector, which are inadequate in quantity and are prone to exhaustion [31,38,40-43]. Development of renewable energy as a main global resource of clean energy is one of the main global purposes of current policies, which, in the overall outline of sustainable development, is intended to reduce energy consumption and increase the security of supply, environmental protection, and maintainable technology development [38].

Forest and agricultural resources are conspicuous sources of energy that may be indispensable for greater local and technological development [23,41,44-47]. For this reason, recent scientific and technical research has sought to mature innovations that allow the larger reuse of resources with clean energy and low environmental impact $[2,3,6,12,14,17]$. 
To become economically sustainable, undeveloped renewable resource-based technologies must progress along the learning curve, finally influencing competitiveness with fossil resource-based options $[8,48,49]$. Furthermore, innovations are fundamental for ensuring environmental sustainability that decreases the potential impacts of renewable resource use on ecosystems $[49,50]$. The employment of a circular flow economy needs original technological, organizational and product solutions, and improved resource efficiency [1,47]. On the supply side, innovations should focus on technologies and products, while from the user side, main concern should be given to consumption and waste generation patterns $[49,51]$.

The innovation lies in the fact that the advancement of energy efficiency is achieved through a gradual move from fossil energy sources to more environmentally friendly and renewable energy sources, endorsing energy efficiency through improved performance technologies and schemes $[8,52,53]$ and affording a combined method reliable with the expansion of the liberalized market. For this purpose, today, a scheme that can assimilate advanced and innovative essentials of tariff control and direct control of the market should be implemented [43].

With the regards a prospective future changeover towards a sustainable bioeconomy, today, policy interventions, technology and product markets results are inadequate in offering suitable encouragements $[49,54,55]$. Furthermore, compulsory fossil resource-based technologies profit from past learning properties, increasing returns, and network externalities, all of which interrelate with the dedicated nature of investments to produce a technological path reliance [49]. Such a framework can be strengthened by a co-evolutionary growth of fossil resource-based organizations, codependent industries, consumption patterns, and private and public institutions ensuing in a "carbon lock-in" [4,7,9].

Research on the relationship among innovation systems, sustainability, and policies focused on energy system transitions [56-59]. Literature offers significant insights concerning appropriate policies, innovation economics, and systems [49,58]. Therefore, an inclusive and well-coordinated policy asset is compulsory to support a well-developed innovation system, which is in turn helpful in providing a sociotechnical path change [56,59].

In the last decade, climate and energy strategy was emphasized by the European declaration towards the achievement of definite environmental goals of energy strategy and advancement of agriculture-based bioenergy and biofuels [41,60-62]. Several global challenges require innovative approaches to knowledge discussion, e.g., those predicted in the European Innovation Partnership "Agricultural Productivity and Sustainability", which are of greatest importance to foster the application of explanations [52]. The change toward agriculture-based bioenergy has also been supported in reply to structural variations in agriculture that involve an examination of new endurance approaches [60].

\subsection{Conjugating Innovation with Biomass}

Climate change, scarcity of resources and materials, increasing population, and environmental pressures have encouraged a revaluation and assessment of the current fossil-based economy $[3,63]$. The bioeconomy concept has been given numerous descriptions and its conceptualization is still developing [64-66]. However, two main features can be shared. Firstly, bioeconomy will depend on renewable biomass in place of finite fossil inputs to produce an extensive variety of value-added products, e.g., bio-based products and bioenergy [3,32,64,67-70]. Secondly, these products will be formed in biorefineries succeeding a cascade principle with the intention of extremely valorizing the obtainable biomass [71,72]. Biomass is originally processed into high value products and the relative residues are used for lower value applications until the smallest amount of waste remains at the conclusion of the process [73-75]. Bioeconomy can therefore be considered an assortment of sectors and subsectors (e.g., agriculture and energy), employed in combination to derive products from renewable biological resources from the primary sector [3,71,72].

According to [3], innovation can develop following specific processes within the bioeconomy based on a four-staged literature research: innovation process, network management, stakeholder groups, and bioeconomy contextual factors. Idea development, invention, and commercialization are 
the three fundamental phases for activating an iterative process. During the latter process, the three fundamental phases are interconnected via learning cycles, enabling repetition of confident process steps to adjust to unexpected progresses and errors (Figure 1).

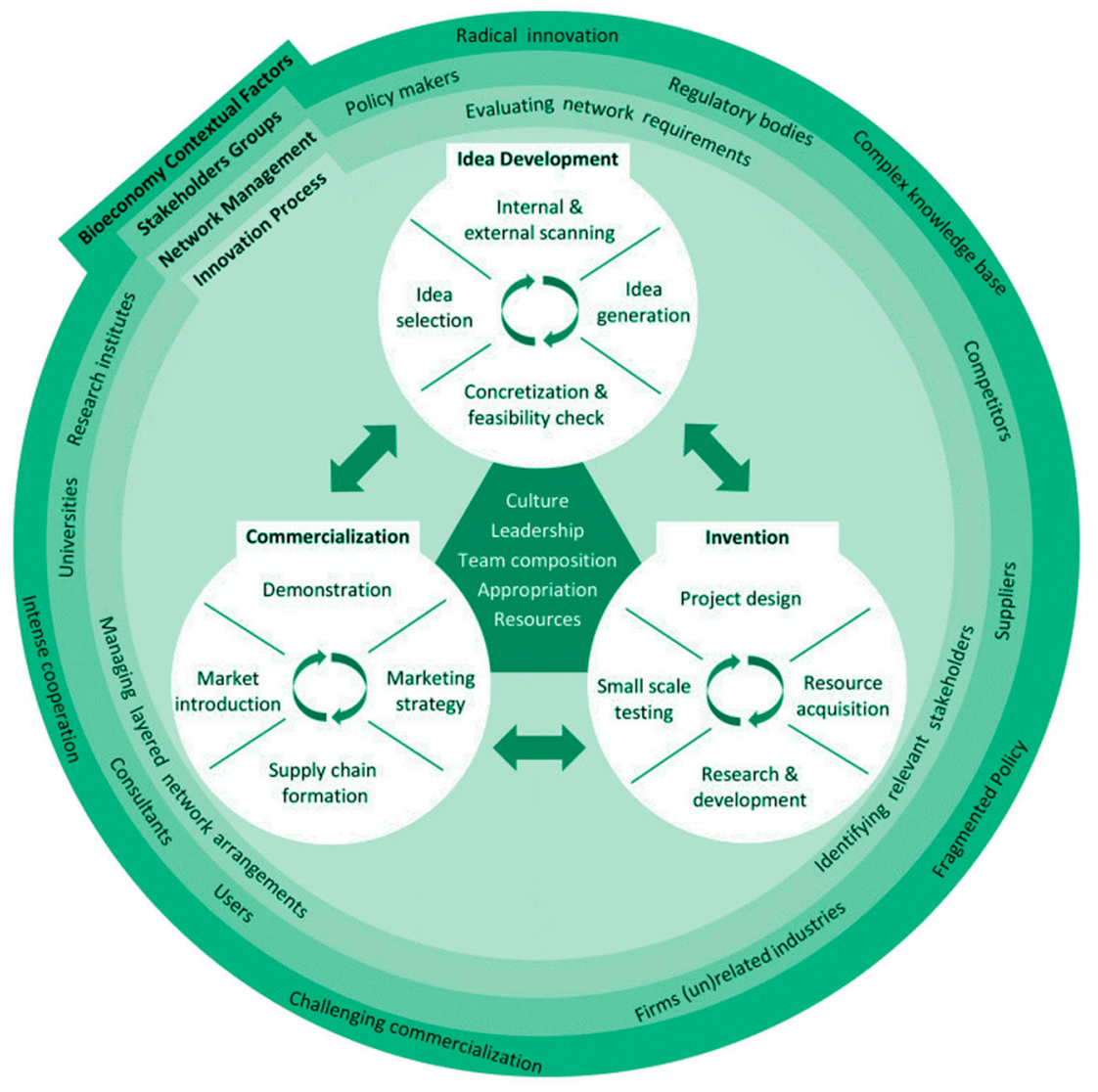

Figure 1. A schematic depiction of innovation in the bioeconomy framework (source: our elaboration with a reproduction with permission from [3], 2016).

Biomass feedstock are energy sources in the primary sector, which are derived from wastes associated with their processing (e.g., agricultural residues) $[6,67,68,70,76]$. However, natural resources for energy purpose expose contrasting opinions. Following some researchers, land-use change for the cultivation of energy crops can have important consequences on global food security, employment, the income of regional populations, and the biodiversity of ecological societies [37,76,77]. Land accessibility, land-use practices, and water availability are some of the main key factors for the large-scale production of biofuels [76,78-80]. A negative perspective has exposed that the future availability of arable land, using existing farming areas for energy crop cultivation, might result in food deficiency [76]. However, it may be practicable to convert abandoned and marginal areas into cultivated land for energy crop cultivation $[32,55,67,69,77]$. Global biofuel programs will usually subsidize the sustainable livelihood of agricultural employees by growing employment rates in most rural contexts since a large portion of feedstock cultivation and plant processing includes manual work [76].

Following a more optimistic perspective, biomass supply may be protected and extended using advanced management procedures and strategies [40,81]. For instance, new sources of cheap biomass for energy production can be selected by using lignocellulosic material that is inappropriate for common forestry and agricultural usage [82].

Investigation into innovations and technologies that can decrease land use and decrease accidents from renewable energy sources and the risk of resource competition have been carried out $[83,84]$. For instance, with bioenergy, food for consumption competes in the same areas as those for energy production [42]. 


\subsection{Conjugating Innovation with Solar Energy}

Innovation in the primary sector also benefits from solar energy [85-89]. Many studies have deepened understanding of this issue since the installation of solar systems on greenhouse structures became one of the recent strategies to allow both agricultural production and energy production [39,46,86,89-91]. However, the installation of photovoltaic panels on greenhouses involves certain limitations, which have been solved through specific studies [39,92]. Shading represents one of the main limitations for photovoltaic installation on the rooves of greenhouses [39,93-96]. The spatial shading variations in a greenhouse during a year can be supposed an appropriate factor for picking out the greatest combination of photovoltaic panels and crops present, guaranteeing both energy and production activities $[52,88]$. The choice of the covering shading on the spectral distribution of solar radiation incoming to greenhouses, the kind of material, and further properties of the greenhouse are crucial for defining pertinent technical structural details, environmental influences, and internal climatic settings [87,97-99].

The question of shade due to the presence of photovoltaic panels on greenhouse rooves, though, is related to the possible reduction of cultivation that is carried out within the greenhouse $[52,100]$. Nevertheless, several studies have already promoted different methods and strategies and projects of innovative greenhouses with the intention of limiting the shadow percentage and ensuring optimal agricultural production $[39,46,85]$.

\section{Discussion}

Innovation is indispensable to reply to the critical apprehensions and challenges related to, for example, climate change, environmental trials, energy scarcity, and food security $[1,13,21,22,27,37,50,76,77,99]$. Numerous novelties will be in the form of products, processes, and services which can improve the success and efficiency of answering to these socioeconomic challenges and dealing with the measurement and mitigation of negative externalities [63].

Greater sustainability in the primary sector can be guaranteed through (i) the use of agricultural residues, i.e., biomass from agricultural and forestry wastes $[16,39,67,68,70,82,101]$, and (ii) renewable energy, e.g., solar energy [39]. The importance of having adequate structures as solar systems installed on greenhouses helping to produce agricultural products is fundamental to maximize space and optimize both agricultural and energy production $[32,39]$.

Agricultural innovation can be considered as a co-evolutionary process where technological, socioeconomic, and institutional changes are combined [4,7,102]. With production and technical knowledge, numerous factors play a crucial role as prerequisites for innovation, for instance, policy, legislation, funding, infrastructure, and market progresses [7]. However, a limited quantity of research is available concerning current technologies and innovations within the primary sector, such as in developed countries [102-104]. The latter countries are mainly vulnerable to environmental influences, e.g., related to climate change [34,42]. Such current challenges usually have an explicit influence on the agricultural and forestry sector [103].

Addressing the current complex and uncontrolled sustainability matters facing the primary sector, innovations must ensure continuous progress by (i) facilitating the development of rural and forestry economic realities, (ii) pursuing greater environmental mitigation, and (iii) bringing the political sphere into line with the more practical one $[5,15,16]$. However, dealing with such current challenges is progressively significant (i) bearing in mind mission-oriented innovation strategies and (ii) underscoring the requirement for innovation systems to achieve specific determinations for a sustainability changeover $[5,10,105]$.

Agricultural innovation is no longer just about approving new technologies, technical practices, and alternative customs of organization [7]. Additionally, agricultural innovation is usually driven by different visions exposing different development directions, e.g., sustainable developments and energy efficiency $[7,8,16,52,53,104]$. However, soil should play a major role in food production in view of another fundamental issue today, namely the increase of both food requirements and the reduction in 
soil availability and fertility due to population growth and the growing phenomena of desertification and soil degradation [106-111]. In this requirement, the sustainability of agricultural practices can make sense of the reduction of waste and the agronomic energy reuse of by-products $[75,82,101]$. The role of energy is decisive in this framework also in view of a sustainable development in which the needs of fossil fuels (to produce energy biomass) must assess and reflect on the proper use of agricultural areas and in the recovery of abandoned and marginal areas, even where energy crops are grown $[8,43]$.

\section{Conclusion}

Energy can assume a key role in current innovations, highlighting chances and limitations for sustainable development $[32,33,38,39,76,82,83,112-115]$. In this review, the primary sector is investigated due to different issues, e.g., alternative systems of agriculture, more sustainable modernizations in agricultural and forestry [116], reuse of rural land [75,77,82,101,107,116], environmental respect avoiding stress on natural resources, e.g., soil, which can lead to degenerative phenomena, e.g., soil degradation, which are especially severe if they relate to the loss of high-quality soils $[37,80,106-111]$. Innovation has become increasingly applied to survey the organization of joint technological, social, and institutional modernizations in the primary sector $[6,99,103,106,113]$. Sightseeing the governance of actor relations, latent policies, and support structures is critical to the stage of innovation, e.g., during research activities, at different spatial scales $[117,118]$. Modernizations in agriculture and forestry may contribute to planning more sustainable systems, even including energy as a fourth dimension together with economy, society, and environment $[32,33,116]$. In fact, energy sustainability has become a crucial question in recent years, especially where progressive technological progress is necessary to ensure long-lasting energy efficiency.

Author Contributions: Conceptualization, I.Z. and A.C.; methodology, M.C.; validation, E.M.M. and A.C.; formal analysis, I.Z.; investigation, I.Z., M.C., and A.C.; writing-original draft preparation, I.Z.; writing-review and editing, I.Z., M.C., E.M.M., and A.C.

Funding: The research was partially supported by the Italian Ministry for Education, University and Research (MIUR) according to the Italian Law 232/2016 within the fund for the financing of universities "Departments of Excellence".

Conflicts of Interest: The authors declare no conflict of interest.

\section{References}

1. Carus, M.; Dammer, L. Food or Non-Food: Which Agricultural Feedstocks Are Best for Industrial Uses? Ind. Biotechnol. 2013, 9, 171-176. [CrossRef]

2. Hellsmark, H.; Mossberg, J.; Söderholm, P.; Frishammar, J. Innovation system strengths and weaknesses in progressing sustainable technology: The case of Swedish biorefinery development. J. Clean. Prod. 2016, 131, 702-715. [CrossRef]

3. Van Lancker, J.; Wauters, E.; Van Huylenbroeck, G. Managing innovation in the bioeconomy: An open innovation perspective. Biomass Bioenergy 2016, 90, 60-69. [CrossRef]

4. Kilelu, C.W.; Klerkx, L.; Leeuwis, C. Unravelling the role of innovation platforms in supporting co-evolution of innovation: Contributions and tensions in a smallholder dairy development programme. Agric. Syst. 2013, 118, 65-77. [CrossRef]

5. Pigford, A.-A.E.; Hickey, G.M.; Klerkx, L. Beyond agricultural innovation systems? Exploring an agricultural innovation ecosystems approach for niche design and development in sustainability transitions. Agric. Syst. 2018, 164, 116-121. [CrossRef]

6. Turner, J.A.; Klerkx, L.; Rijswijk, K.; Williams, T.; Barnard, T. Systemic problems affecting co-innovation in the New Zealand Agricultural Innovation System: Identification of blocking mechanisms and underlying institutional logics. NJAS Wagening. J. Life Sci. 2016, 76, 99-112. [CrossRef] 
7. Klerkx, L.; Van Mierlo, B.; Leeuwis, C. Evolution of Systems Approaches to Agricultural Innovation: Concepts, Analysis and Interventions, Farming Systems Research into the 21st Century: The New Dynamic; Springer: Berlin/Heidelberg, Germany, 2012; pp. 457-483.

8. Ingrao, C.; Bacenetti, J.; Bezama, A.; Blok, V.; Goglio, P.; Koukios, E.G.; Lindner, M.; Nemecek, T.; Siracusa, V.; Zabaniotou, A.; et al. The potential roles of bio-economy in the transition to equitable, sustainable, post fossil-carbon societies: Findings from this virtual special issue. J. Clean. Prod. 2018, 204, 471-488. [CrossRef]

9. Plumecocq, G.; Debril, T.; Duru, M.; Magrini, M.-B.; Sarthou, J.P.; Therond, O. The plurality of values in sustainable agriculture models: Diverse lock-in and coevolution patterns. Ecol. Soc. 2018, 23, 21. [CrossRef]

10. Schlaile, M.P.; Urmetzer, S.; Blok, V.; Andersen, A.D.; Timmermans, J.; Mueller, M.; Fagerberg, J.; Pyka, A. Innovation Systems for Transformations towards Sustainability? Taking the Normative Dimension Seriously. Sustainability 2017, 9, 2253. [CrossRef]

11. Stirling, A. Pluralising progress: From integrative transitions to transformative diversity. Environ. Innov. Soc. Transit. 2011, 1, 82-88. [CrossRef]

12. Touzard, J.-M.; Temple, L.; Faure, G.; Triomphe, B. Innovation systems and knowledge communities in the agriculture and agrifood sector: A literature review. J. Innov. Econ. 2015, 17, 117. [CrossRef]

13. Foran, T.; Butler, J.R.; Williams, L.J.; Wanjura, W.J.; Hall, A.; Carter, L.; Carberry, P.S. Taking Complexity in Food Systems Seriously: An Interdisciplinary Analysis. World Dev. 2014, 61, 85-101. [CrossRef]

14. Wigboldus, S.; Klerkx, L.; Leeuwis, C.; Schut, M.; Muilerman, S.; Jochemsen, H. Systemic perspectives on scaling agricultural innovations. A review. Agron. Sustain. Dev. 2016, 36, 46. [CrossRef]

15. Meynard, J.-M.; Jeuffroy, M.-H.; Le Bail, M.; Lefèvre, A.; Magrini, M.-B.; Michon, C. Designing coupled innovations for the sustainability transition of agrifood systems. Agric. Syst. 2017, 157, 330-339. [CrossRef]

16. Prost, L.; Berthet, E.T.; Cerf, M.; Jeuffroy, M.H.; Labatut, J.; Meynard, J.M. Innovative design for agriculture in the move towards sustainability: Scientific challenges. Res. Eng. Des. 2017, 28, 119-129. [CrossRef]

17. Bennett, E.; Carpenter, S.; Gordon, L.; Ramankutty, N.; Balvanera, P.; Campbell, B.; Cramer, W.; Foley, J.; Folke, C.; Karlberg, L. Toward a more resilient agriculture. Solutions 2014, 5, 65-75.

18. FAO (Food and Agriculture Organization). Building a Common Vision for Sustainable Food and Agriculture: Principles and Approaches; Food and Agriculture Organization of the United Nations: Rome, Italy, 2014.

19. FAO (Food and Agriculture Organization). The State of Food and Agriculture 2016 (SOFA): Climate Change, Agriculture and Food Security; Food and Agriculture Organization of the United Nations: Rome, Italy, 2016.

20. Hall, A.; Clark, N. What do complex adaptive systems look like and what are the implications for innovation policy? J. Int. Dev. 2010, 22, 308-324. [CrossRef]

21. Bommarco, R.; Kleijn, D.; Potts, S.G. Ecological intensification: Harnessing ecosystem services for food security. Trends Ecol. Evol. 2013, 28, 230-238. [CrossRef]

22. Ville, A.S.S.; Hickey, G.M.; Phillip, L.E. Addressing food and nutrition insecurity in the Caribbean through domestic smallholder farming system innovation. Reg. Environ. Chang. 2015, 15, 1325-1339. [CrossRef]

23. Berthet, E.T.; Segrestin, B.; Hickey, G.M. Considering agro-ecosystems as ecological funds for collective design: New perspectives for environmental policy. Environ. Sci. Policy 2016, 61, 108-115. [CrossRef]

24. Svensson, O.; Nikoleris, A. Structure reconsidered: Towards new foundations of explanatory transitions theory. Res. Policy 2018, 47, 462-473. [CrossRef]

25. Arts, B.; Buizer, M.; Horlings, L.; Ingram, V.; Van Oosten, C.; Opdam, P. Landscape Approaches: A State-of-the-Art Review. Annu. Rev. Environ. Resour. 2017, 42, 439-463. [CrossRef]

26. Sayer, J.; Sunderland, T.; Ghazoul, J.; Pfund, J.-L.; Sheil, D.; Meijaard, E.; Venter, M.; Boedhihartono, A.K.; Day, M.; Garcia, C.; et al. Ten principles for a landscape approach to reconciling agriculture, conservation, and other competing land uses. Proc. Natl. Acad. Sci. USA 2013, 110, 8349-8356. [CrossRef] [PubMed]

27. Brooks, S.; Loevinsohn, M. Shaping agricultural innovation systems responsive to food insecurity and climate change. Nat. Resour. Forum 2011, 35, 185-200. [CrossRef]

28. Rockström, J.; Williams, J.; Daily, G.; Noble, A.; Matthews, N.; Gordon, L.; Wetterstrand, H.; DeClerck, F.; Shah, M.; Steduto, P. Sustainable intensification of agriculture for human prosperity and global sustainability. Ambio 2017, 46, 4-17. [CrossRef]

29. Hassink, J.; Grin, J.; Hulsink, W. Multifunctional Agriculture Meets Health Care: Applying the Multi-Level Transition Sciences Perspective to Care Farming in the Netherlands. Sociol. Rural. 2013, 53, 223-245. [CrossRef] 
30. Hassink, J.; Grin, J.; Hulsink, W. Enriching the multi-level perspective by better understanding agency and challenges associated with interactions across system boundaries. The case of care farming in the Netherlands: Multifunctional agriculture meets health care. J. Rural. Stud. 2018, 57, 186-196. [CrossRef]

31. Sutherland, L.-A.; Peter, S.; Zagata, L. Conceptualising multi-regime interactions: The role of the agriculture sector in renewable energy transitions. Res. Policy 2015, 44, 1543-1554. [CrossRef]

32. Zambon, I.; Colantoni, A.; Cecchini, M.; Mosconi, E.M. Rethinking Sustainability within the Viticulture Realities Integrating Economy, Landscape and Energy. Sustainability 2018, 10, 320. [CrossRef]

33. Bonazzi, F.A.; Cividino, S.R.; Zambon, I.; Mosconi, E.M.; Poponi, S. Building Energy Opportunity with a Supply Chain Based on the Local Fuel-Producing Capacity. Sustainability 2018, 10, 2140. [CrossRef]

34. Jeong, J.S. Biomass Feedstock and Climate Change in Agroforestry Systems: Participatory Location and Integration Scenario Analysis of Biomass Power Facilities. Energies 2018, 11, 1404. [CrossRef]

35. Moulogianni, C.; Bournaris, T. Biomass Production from Crops Residues: Ranking of Agro-Energy Regions. Energies 2017, 10, 1061. [CrossRef]

36. Sharara, M.A.; Sadaka, S.S. Opportunities and Barriers to Bioenergy Conversion Techniques and Their Potential Implementation on Swine Manure. Energies 2018, 11, 957. [CrossRef]

37. Altieri, M.A.; Nicholls, C.I. The adaptation and mitigation potential of traditional agriculture in a changing climate. Clim. Chang. 2017, 140,33-45. [CrossRef]

38. Aschilean, I.; Rasoi, G.; Raboaca, M.S.; Filote, C.; Culcer, M. Design and Concept of an Energy System Based on Renewable Sources for Greenhouse Sustainable Agriculture. Energies 2018, 11, 1201. [CrossRef]

39. Marucci, A.; Zambon, I.; Colantoni, A.; Monarca, D. A combination of agricultural and energy purposes: Evaluation of a prototype of photovoltaic greenhouse tunnel. Renew. Sustain. Energy Rev. 2018, 82, 1178-1186. [CrossRef]

40. Fontes, C.H.D.O.; Freires, F.G.M. Sustainable and renewable energy supply chain: A system dynamics overview. Renew. Sustain. Energy Rev. 2018, 82, 247-259.

41. Lyytimäki, J. Renewable energy in the news: Environmental, economic, policy and technology discussion of biogas. Sustain. Prod. Consum. 2018, 15, 65-73. [CrossRef]

42. Owusu, P.A.; Asumadu-Sarkodie, S. A review of renewable energy sources, sustainability issues and climate change mitigation. Cogent Eng. 2016, 3, 1167990. [CrossRef]

43. Romano, S.; Cozzi, M.; Di Napoli, F.; Viccaro, M. Building Agro-Energy Supply Chains in the Basilicata Region: Technical and Economic Evaluation of Interchangeability between Fossil and Renewable Energy Sources. Energies 2013, 6, 5259-5282. [CrossRef]

44. Agrawal, A.; Nepstad, D.; Chhatre, A. Reducing Emissions from Deforestation and Forest Degradation. Annu. Rev. Environ. Resour. 2011, 36, 373-396. [CrossRef]

45. Bentsen, N.S.; Felby, C. Biomass for energy in the European Union-A review of bioenergy resource assessments. Biotechnol. Biofuels 2012, 5, 25. [CrossRef]

46. Carreño-Ortega, A.; Galdeano-Gómez, E.; Pérez-Mesa, J.C.; Galera-Quiles, M.D.C. Policy and Environmental Implications of Photovoltaic Systems in Farming in Southeast Spain: Can Greenhouses Reduce the Greenhouse Effect? Energies 2017, 10, 761. [CrossRef]

47. Ghisellini, P.; Cialani, C.; Ulgiati, S. A review on circular economy: The expected transition to a balanced interplay of environmental and economic systems. J. Clean. Prod. 2016, 114, 11-32. [CrossRef]

48. Osmani, A.; Zhang, J.; Gonela, V.; Awudu, I. Electricity generation from renewables in the United States: Resource potential, current usage, technical status, challenges, strategies, policies, and future directions. Renew. Sustain. Energy Rev. 2013, 24, 454-472. [CrossRef]

49. Purkus, A.; Hagemann, N.; Bedtke, N.; Gawel, E. Towards a sustainable innovation system for the German wood-based bioeconomy: Implications for policy design. J. Clean. Prod. 2018, 172, 3955-3968. [CrossRef]

50. Sala, S.; Anton, A.; McLaren, S.J.; Notarnicola, B.; Saouter, E.; Sonesson, U. In quest of reducing the environmental impacts of food production and consumption. J. Clean. Prod. 2017, 140, 387-398. [CrossRef]

51. Miceli, R. Energy management and smart grids. Energies 2013, 6, 2262-2290. [CrossRef]

52. Becerril, H.; Rios, I.D.L. Energy Efficiency Strategies for Ecological Greenhouses: Experiences from Murcia (Spain). Energies 2016, 9, 866. [CrossRef]

53. Gadenne, D.; Sharma, B.; Kerr, D.; Smith, T.; Kerr, D.; Smith, T. The influence of consumers' environmental beliefs and attitudes on energy saving behaviours. Energy Policy 2011, 39, 7684-7694. [CrossRef] 
54. Hagemann, N.; Gawel, E.; Purkus, A.; Pannicke, N.; Hauck, J. Possible Futures towards a Wood-Based Bioeconomy: A Scenario Analysis for Germany. Sustainability 2016, 8, 98. [CrossRef]

55. Horlings, L.; Kanemasu, Y. Sustainable development and policies in rural regions; insights from the Shetland Islands. Land Use Policy 2015, 49, 310-321. [CrossRef]

56. Gallagher, K.S.; Grubler, A.; Kuhl, L.; Nemet, G.; Wilson, C. The Energy Technology Innovation System. Annu. Rev. Environ. Resour. 2012, 37, 137-162. [CrossRef]

57. Markard, J.; Raven, R.; Truffer, B. Sustainability transitions: An emerging field of research and its prospects. Res. Policy 2012, 41, 955-967. [CrossRef]

58. Ahorsu, R.; Medina, F.; Constantí, M. Significance and Challenges of Biomass as a Suitable Feedstock for Bioenergy and Biochemical Production: A Review. Energies 2018, 11, 3366. [CrossRef]

59. Edquist, C.; Zabala-Iturriagagoitia, J.M. Public Procurement for Innovation as mission-oriented innovation policy. Res. Policy 2012, 41, 1757-1769. [CrossRef]

60. Isoaho, K.; Karhunmaa, K. A critical review of discursive approaches in energy transitions. Energy Policy 2019, 128, 930-942. [CrossRef]

61. Kivimaa, P.; Hildén, M.; Huitema, D.; Jordan, A.; Newig, J. Experiments in climate governance-A systematic review of research on energy and built environment transitions. J. Clean. Prod. 2017, 169, 17-29. [CrossRef]

62. Kortelainen, J.; Rytteri, T. EU policy on the move-mobility and domestic translation of the European Union's renewable energy policy. J. Environ. Policy Plan. 2017, 19, 360-373. [CrossRef]

63. Boehlje, M.; Bröring, S. The increasing multifunctionality of agricultural raw materials: Three dilemmas for innovation and adoption. Int. Food Agribus. Manag. Rev. 2011, 14, 1-16.

64. Pfau, S.F.; Hagens, J.E.; Dankbaar, B.; Smits, A.J.M. Visions of Sustainability in Bioeconomy Research. Sustainability 2014, 6, 1222-1249. [CrossRef]

65. Pülzl, H.; Kleinschmit, D.; Arts, B. Bioeconomy-An emerging meta-discourse affecting forest discourses? Scand. J. For. Res. 2014, 29, 386-393. [CrossRef]

66. Vandermeulen, V.; Van Der Steen, M.; Stevens, C.V.; Van Huylenbroeck, G. Industry expectations regarding the transition toward a biobased economy. Biofuels Bioprod. Biorefin. 2012, 6, 453-464. [CrossRef]

67. Colantoni, A.; Delfanti, L.; Recanatesi, F.; Tolli, M.; Lord, R. Land use planning for utilizing biomass residues in Tuscia Romana (central Italy): Preliminary results of a multi criteria analysis to create an agro-energy district. Land Use Policy 2016, 50, 125-133. [CrossRef]

68. Colantoni, A.; Evic, N.; Lord, R.; Retschitzegger, S.; Proto, A.R.; Gallucci, F.; Monarca, D. Characterization of biochars produced from pyrolysis of pelletized agricultural residues. Renew. Sustain. Energy Rev. 2016, 64, 187-194. [CrossRef]

69. Johnson, T.G.; Altman, I. Rural development opportunities in the bioeconomy. Biomass Bioenergy 2014, 63, 341-344. [CrossRef]

70. Zambon, I.; Colosimo, F.; Monarca, D.; Cecchini, M.; Gallucci, F.; Proto, A.R.; Lord, R.; Colantoni, A. An Innovative Agro-Forestry Supply Chain for Residual Biomass: Physicochemical Characterisation of Biochar from Olive and Hazelnut Pellets. Energies 2016, 9, 526. [CrossRef]

71. De Besi, M.; McCormick, K. Towards a Bioeconomy in Europe: National, Regional and Industrial Strategies. Sustainability 2015, 7, 10461-10478. [CrossRef]

72. McCormick, K.; Kautto, N. The Bioeconomy in Europe: An Overview. Sustainability 2013, 5, $2589-2608$. [CrossRef]

73. Fritsche, U.R.; Iriarte, L. Sustainability Criteria and Indicators for the Bio-Based Economy in Europe: State of Discussion and Way Forward. Energies 2014, 7, 6825-6836. [CrossRef]

74. Keegan, D.; Kretschmer, B.; Elbersen, B.; Panoutsou, C. Cascading use: A systematic approach to biomass beyond the energy sector. Biofuels Bioprod. Biorefin. 2013, 7, 193-206. [CrossRef]

75. Zwier, J.; Blok, V.; Lemmens, P.; Geerts, R.-J. The Ideal of a Zero-Waste Humanity: Philosophical Reflections on the Demand for a Bio-Based Economy. J. Agric. Environ. Ethic 2015, 28, 353-374. [CrossRef]

76. Srirangan, K.; Akawi, L.; Moo-Young, M.; Chou, C.P. Towards sustainable production of clean energy carriers from biomass resources. Appl. Energy 2012, 100, 172-186. [CrossRef]

77. Selvaggi, R.; Valenti, F.; Pappalardo, G.; Rossi, L.; Bozzetto, S.; Pecorino, B.; Dale, B.E. Sequential crops for food, energy, and economic development in rural areas: The case of Sicily. Biofuels Bioprod. Biorefin. 2018, 12, 22-28. [CrossRef] 
78. Creutzig, F.; Ravindranath, N.H.; Berndes, G.; Bolwig, S.; Bright, R.; Cherubini, F.; Fargione, J. Bioenergy and climate change mitigation: An assessment. GCB Bioenergy 2015, 7, 916-944. [CrossRef]

79. Erb, K.H.; Luyssaert, S.; Meyfroidt, P.; Pongratz, J.; Don, A.; Kloster, S.; Haberl, H. Land management: Data availability and process understanding for global change studies. Glob. Chang. Biol. 2017, 23, 512-533. [CrossRef] [PubMed]

80. Keesstra, S.; Nunes, J.P.; Novara, A.; Finger, D.; Avelar, D.; Kalantari, Z.; Cerdà, A. The superior effect of nature based solutions in land management for enhancing ecosystem services. Sci. Total Environ. 2018, 610, 997-1009. [CrossRef] [PubMed]

81. Gold, S.; Seuring, S. Supply chain and logistics issues of bio-energy production. J. Clean. Prod. 2011, 19, 32-42. [CrossRef]

82. Al-Hamamre, Z.; Saidan, M.; Hararah, M.; Rawajfeh, K.; Alkhasawneh, H.E.; Al-Shannag, M. Wastes and biomass materials as sustainable-renewable energy resources for Jordan. Renew. Sustain. Energy Rev. 2017, 67, 295-314. [CrossRef]

83. Dincer, I.; Acar, C. Smart energy systems for a sustainable future. Appl. Energy 2017, 194, 225-235. [CrossRef]

84. Mafakheri, F.; Nasiri, F. Modeling of biomass-to-energy supply chain operations: Applications, challenges and research directions. Energy Policy 2014, 67, 116-126. [CrossRef]

85. Colantoni, A.; Monarca, D.; Marucci, A.; Cecchini, M.; Zambon, I.; Di Battista, F.; Maccario, D.; Saporito, M.G.; Beruto, M. Solar Radiation Distribution inside a Greenhouse Prototypal with Photovoltaic Mobile Plant and Effects on Flower Growth. Sustainability 2018, 10, 855. [CrossRef]

86. Hassanien, R.H.E.; Li, M.; Lin, W.D. Advanced applications of solar energy in agricultural greenhouses. Renew. Sustain. Energy Rev. 2016, 54, 989-1001. [CrossRef]

87. Kavga, A.; Souliotis, M.; Koumoulos, E.P.; Fokaides, P.A.; Charitidis, C.A. Environmental and nanomechanical testing of an alternative polymer nanocomposite greenhouse covering material. Sol. Energy 2018, 159, 1-9. [CrossRef]

88. Ureña-Sánchez, R.; Callejón-Ferre, Á.J.; Pérez-Alonso, J.; Carreño-Ortega, Á. Greenhouse tomato production with electricity generation by roof-mounted flexible solar panels. Sci. Agric. 2012, 69, 233-239. [CrossRef]

89. Sahu, B.K. A study on global solar PV energy developments and policies with special focus on the top ten solar PV power producing countries. Renew. Sustain. Energy Rev. 2015, 43, 621-634. [CrossRef]

90. Castillo, C.P.; Silva, F.B.E.; LaValle, C. An assessment of the regional potential for solar power generation in EU-28. Energy Policy 2016, 88, 86-99. [CrossRef]

91. De Luca, G.; Fabozzi, S.; Massarotti, N.; Vanoli, L. A renewable energy system for a nearly zero greenhouse city: Case study of a small city in southern Italy. Energy 2018, 143, 347-362. [CrossRef]

92. Simeoni, P.; Nardin, G.; Ciotti, G. Planning and design of sustainable smart multi energy systems. The case of a food industrial district in Italy. Energy 2018, 163, 443-456. [CrossRef]

93. Trypanagnostopoulos, G.; Kavga, A.; Souliotis, M.; Tripanagnostopoulos, Y. Greenhouse performance results for roof installed photovoltaics. Renew. Energy 2017, 111, 724-731. [CrossRef]

94. Pérez-Alonso, J.; Pérez-García, M.; Pasamontes-Romera, M.; Callejon-Ferre, A.J. Performance analysis and neural modelling of a greenhouse integrated photovoltaic system. Renew. Sustain. Energy Rev. 2012, 16, 4675-4685. [CrossRef]

95. Tudisca, S.; Di Trapani, A.M.; Sgroi, F.; Testa, R.; Squatrito, R. Economic analysis of PV systems on buildings in Sicilian farms. Renew. Sustain. Energy Rev. 2013, 28, 691-701. [CrossRef]

96. Tudisca, S.; Di Trapani, A.M.; Sgroi, F.; Testa, R.; Squatrito, R. Assessment of Italian energy policy through the study of a photovoltaic investment on greenhouse. Afr. J. Agric. Res. 2013, 8, 3089-3096.

97. Both, A.J.; Benjamin, L.; Franklin, J.; Holroyd, G.; Incoll, L.D.; Lefsrud, M.G.; Pitkin, G. Guidelines for measuring and reporting environmental parameters for experiments in greenhouses. Plant Methods 2015, 11, 43. [CrossRef] [PubMed]

98. Cuce, E.; Harjunowibowo, D. Renewable and sustainable energy saving strategies for greenhouse systems: A comprehensive review. Renew. Sustain. Energy Rev. 2016, 64, 34-59. [CrossRef]

99. Ghoulem, M.; El Moueddeb, K.; Nehdi, E.; Boukhanouf, R.; Calautit, J.K. Greenhouse design and cooling technologies for sustainable food cultivation in hot climates: Review of current practice and future status. Biosyst. Eng. 2019, 183, 121-150. [CrossRef] 
100. Marucci, A.; Monarca, D.; Cecchini, M.; Colantoni, A.; Cappuccini, A. Analysis of internal shading degree to a prototype of dynamics photovoltaic greenhouse through simulation software. J. Agric. Eng. 2015, 46, 144. [CrossRef]

101. Carlini, M.; Mosconi, E.M.; Castellucci, S.; Villarini, M.; Colantoni, A. An Economical Evaluation of Anaerobic Digestion Plants Fed with Organic Agro-Industrial Waste. Energies 2017, 10, 1165. [CrossRef]

102. Leeuwis, C.; Aarts, N. Rethinking Communication in Innovation Processes: Creating Space for Change in Complex Systems. J. Agric. Educ. Ext. 2011, 17, 21-36. [CrossRef]

103. Long, T.B.; Blok, V.; Coninx, I. Barriers to the adoption and diffusion of technological innovations for climate-smart agriculture in Europe: Evidence from the Netherlands, France, Switzerland and Italy. J. Clean. Prod. 2016, 112, 9-21. [CrossRef]

104. Smith, A.; Voß, J.-P.; Grin, J. Innovation studies and sustainability transitions: The allure of the multi-level perspective and its challenges. Res. Policy 2010, 39, 435-448. [CrossRef]

105. Mazzucato, M. From market fixing to market-creating: A new framework for innovation policy. Ind. Innov. 2016, 23, 140-156. [CrossRef]

106. Zdruli, P.; Lal, R.; Cherlet, M.; Kapur, S. New world atlas of desertification and issues of carbon sequestration, organic carbon stocks, nutrient depletion and implications for food security. In Carbon Management, Technologies, and Trends in Mediterranean Ecosystems; Springer: Cham, Switzerland, 2017; pp. 13-25.

107. Zambon, I.; Sabbi, A.; Schuetze, T.; Salvati, L. Exploring forest 'fringescapes': urban growth, society and swimming pools as a sprawl landmark in coastal Rome. Rend. Lincei 2015, 26, 159-168. [CrossRef]

108. Islam, M.S.; Wong, A.T. Climate Change and Food In/Security: A Critical Nexus. Environments 2017, 4, 38. [CrossRef]

109. Keesstra, S.D.; Bouma, J.; Wallinga, J.; Tittonell, P.; Smith, P.; Cerdà, A.; Montanarella, L.; Quinton, J.N.; Pachepsky, Y.; Van Der Putten, W.H.; et al. The significance of soils and soil science towards realization of the United Nations Sustainable Development Goals. Soil 2016, 2, 111-128. [CrossRef]

110. Tóth, G.; Hermann, T.; Da Silva, M.R.; Montanarella, L. Monitoring soil for sustainable development and land degradation neutrality. Environ. Monit. Assess. 2018, 190, 57. [CrossRef]

111. Gomiero, T. Soil Degradation, Land Scarcity and Food Security: Reviewing a Complex Challenge. Sustainability 2016, 8, 281. [CrossRef]

112. Geissdoerfer, M.; Savaget, P.; Bocken, N.M.; Hultink, E.J. The Circular Economy-A new sustainability paradigm? J. Clean. Prod. 2017, 143, 757-768. [CrossRef]

113. Anadon, L.D.; Chan, G.; Harley, A.G.; Matus, K.; Moon, S.; Murthy, S.L.; Clark, W.C. Making technological innovation work for sustainable development. Proc. Natl. Acad. Sci. USA 2016, 113, 9682-9690. [CrossRef]

114. Shahbaz, M.; Mallick, H.; Mahalik, M.K.; Sadorsky, P. The role of globalization on the recent evolution of energy demand in India: Implications for sustainable development. Energy Econ. 2016, 55, 52-68. [CrossRef]

115. Stock, T.; Obenaus, M.; Kunz, S.; Kohl, H. Industry 4.0 as enabler for a sustainable development: A qualitative assessment of its ecological and social potential. Process. Saf. Environ. Prot. 2018, 118, 254-267. [CrossRef]

116. Knickel, K.; Redman, M.; Darnhofer, I.; Ashkenazy, A.; Chebach, T.C.; Šūmane, S.; Tisenkopfs, T.; Zemeckis, R.; Atkociuniene, V.; Rivera, M.; et al. Between aspirations and reality: Making farming, food systems and rural areas more resilient, sustainable and equitable. J. Rural. Stud. 2018, 59, 197-210. [CrossRef]

117. Secco, L.; Favero, M.; Masiero, M.; Pettenella, D.M. Failures of political decentralization in promoting network governance in the forest sector: Observations from Italy. Land Use Policy 2017, 62, 79-100. [CrossRef]

118. Bosworth, G.; Rizzo, F.; Marquardt, D.; Strijker, D.; Haartsen, T.; Thuesen, A.A. Identifying social innovations in European local rural development initiatives. Innov. Eur. J. Soc. Sci. Res. 2016, 29, 442-461. [CrossRef]

(C) 2019 by the authors. Licensee MDPI, Basel, Switzerland. This article is an open access article distributed under the terms and conditions of the Creative Commons Attribution (CC BY) license (http://creativecommons.org/licenses/by/4.0/). 